\title{
ARGITELEFONIVESTLUSE LÕPETAMISEL KASUTATAVAD KEELELISED VAHENDID ${ }^{1}$
}

\author{
ANDRIELA RÄÄBIS
}

\begin{abstract}
Annotatsioon. Artiklis vaadeldakse eesti argitelefonivestluste lõpetussegmenti, keskendudes selle esimesele ning viimasele osale: lõpumärguande- ja hüvastijätusekventsile. Uuritakse nende sekventside keelelist vormistust ning keeleliste vahendite valiku seoseid sotsiaalsete ja situatiivsete teguritega (osalejate vanus, sugu, suhted ja sotsiaalsed rollid, kontaktide sagedus, vestlustüüp). Analüüsi aluseks on 209 argitelefonikõnet Tartu Ülikooli suulise eesti keele korpusest.
\end{abstract}

Võtmesõnad: suuline kõne, telefonivestluse lõpetamine, lõpumärguanne, hüvastijätt, eesti keel

\section{Sissejuhatus}

Institutsionaalsed telefonikõned (nt intervjuud, häirekeskuse kõned, infoküsimised) on tüüpiliselt kindla struktuuriga. Argised telefonivestlused on aga ülesehituselt üsna eripalgelised: teemade vahel ei pruugi olla selgeid piire ning juba käsitletud teemade juurde võidakse tagasi pöörduda. Neis vestlustes on selgelt struktureeritud ainult algused ja lõpud. Eesti argitelefonivestluste sissejuhatusi on vaadeldud siinkirjutaja väitekirjas (Rääbis 2009), lõpetamist käsitletakse käesolevas artiklis. Artikkel seostub eesti institutsionaalsete telefonikõnede lõpetamise käsitlusega (Rääbis 2002), milles võeti vaatluse alla lõpetussegmendi kaks esimest vooru (Iõpumärguanne ja reaktsioon sellele) ega analüüsitud lõpetamist mõjutavaid sotsiaalseid ja situatiivseid tegureid. Institutsionaalsete infodialoogide lõpetamist on lühidalt käsitletud ka dialoogiaktide tüpoloogia

\footnotetext{
Artikli valmimist on toetanud Euroopa Regionaalarengu Fond Eesti Arvutiteaduse Tippkeskuse kaudu, Eesti Teadusfond (grant 8558), Haridus- ja Teadusministeerium (projektid SF0180078s08 ja EKT8), Alfred Kordelini Sihtasutuse Eesti Fond. Autor on nõuannete eest tänulik Tiit Hennostele.
} 
raames (Hennoste, Rääbis 2004: 48). Käesolevas artiklis uuritakse eesti argitelefonivestluste lõpetussegmente: lõpetussegmendi struktuuri, eri sotsiaalsete tegevuste sooritamiseks kasutatavaid keelelisi vahendeid ning tegevuste ja keeleliste vahendite valiku seoseid osalejate sotsiaalsete omaduste ja situatiivsete teguritega. Keskendutakse lõpumärguande- ja hüvastijätusekventsile. Artikli viimases osas võrreldakse argi- ja institutsionaalsete telefonikõnede lõpetamist.

\section{Varasemad uurimused}

Telefonivestluste lõpetamist on uuritud vestlusanalüüsi, viisakusteooria, kvantitatiivse diskursuseanalüüsi ja sotsiolingvistika raames. Vestlusanalüütilised uurimused on keskendunud lõpetussegmendi struktuurile. Viisakusteooriast (Brown, Levinson 1987) lähtudes rõhutatakse, et vestlus tuleb lõpetada viisil, mis ei ohusta vestluskaaslase nägu (face). Sotsiolingvistika raamistikus on välja toodud lõpetamist mõjutavaid situatiivseid ja sotsiaalseid tegureid.

Telefonivestluste uurijad on näidanud, et lõpetussegment koosneb kolmest osast (Schegloff, Sacks 1973; Kurhila 1996; Placencia 1997; Coronel-Molina 1998; Pavlidou 1998; Takami 2002; Sun 2005; Etehadieh 2011).

1. Lõpumärguanne ja reaktsioon sellele. Lõpumärguanne osutab, et ühe kõneleja jaoks on teemad ammendatud ja vestluse võib lõpetada. Teisel kõnelejal on lõpumärguande järel kaks põhimõttelist võimalust: lõpetamisega nõustuda või vestlust jätkata.

Lõpumärguandeid on kaht tüüpi: implitsiitsed ja eksplitsiitsed. Implitsiitsed lõpumärguanded ei viita otseselt lõpetamisele. Need jagunevad omakorda kaheks: lühivariandid (okei; selge) ja pikemad variandid (nt kokkuvõtted eelnevast jutust, kokkulepped jms). Eksplitsiitsed märguanded osutavad otseselt lõpetamisele (kule=ma lõpetan siis ‘̈ra.). Nendega võidakse viidata nii enda kui ka vestluskaaslase olukorrale, samuti välistele asjaoludele, mis lõpetama sunnivad.

Eri tüüpi märguannete kasutamisel tulevad esile kultuurilised erinevused. Anthony J. Liddicoat (2007: 261) väidab, et ingliskeelsetes vestlustes lõpetamist enamasti eksplitsiitselt ei algatata. Hao Sun (2005) on aga leidnud, et Hiina telefonivestlustes kasutatakse valdavalt (90\%) just eksplitsiitseid lõpumärguandeid. 
2. Vaheosa: käsitletud teemade ja kokkulepete kokkuvõtmine, vestluse tulemuse sõnastamine, vestluse üle heameele väljendamine, helistamise põhjuse kordamine ja seletamine, järgmise kontakteerumise lubamine, tänamine, vabandamine, tervituste saatmine, soovimine jm. Osalt võidakse samu vahendeid kasutada ka lõpetamise algatamiseks.

3. Hüvastijätud.

Eri kultuurides on välja toodud lõpetussegmendi ülesehitusega seotud kontekstuaalseid tegureid.

1. Vestlustüüp. Vestlustüübi all mõistetakse suhtluse põhieesmärki: infovestlused on kindlal eesmärgil tehtud kõned (soovitakse midagi küsida, kokku leppida, esitada kutse jms); suhtehoidmisvestlused on sõprade või pereliikmete regulaarsed kõned, mille puhul pole muud helistamise põhjust kui sotsiaalseid suhteid hoida, igapäevastest asjadest lobiseda (vt Drew, Chilton 2000; Rääbis 2009: 30-31). Ecuadori hispaaniakeelseid vestlusi uurinud Maria Placencia (1997) on leidnud, et suhtehoidmisvestlust lõpetades tehakse filosoofilisi kokkuvõtteid (see on elu; nii see on), infovestlustes väljendatakse eksplitsiitselt, et rohkem pole millestki rääkida, korratakse helistamise põhjust. Hiina telefonikõnesid uurinud Hao Sun (2005) seevastu väidab, et info- ja suhtehoidmisvestluste lõpetamine ei erine üksteisest.

2. Osalejate vanus. Noored lõpetavad vestluse lühidalt, vanemad inimesed kasutavad palju viisakusväljendeid isegi siis, kui omavahel sageli kohtutakse (Placencia 1997).

3. Osalejate sugu. Jaapanikeelseid ema-tütre ja isa-tütre telefonikõnesid võrrelnud Emiko Kamimoto (2010) toob esile, et ema ja tütre vestluste lõpetussegmendid on pikemad, lõpetamine katkestatakse korduvalt.

4. Osalejate suhted ja sotsiaalne distants. Lühike lõpetussegment on iseloomulik võõrastele ja lähedastele suhtlejatele, neutraalse suhtlusdistantsi puhul lisanduvad tänamised, vabandused ja nende tagasilükkamised (Placencia 1997).

5. Kontaktide sagedus. Serafin Coronel-Molina (1998) on analüüsinud Ladina-Ameerikast pärit hispaania emakeelega kõnelejate argitelefonivestlusi ja leidnud, et rahvusvaheliste kõnede lõpetussegment on pikem kui kohalikel kõnedel, kuna esimesed toimuvad harvem ning otsitakse põhjusi kontakti võimalikult pikalt hoida.

6. Suhtluse argisus või institutsionaalsus. Välismaalaste soomekeelseid kõnesid uurinud Salla Kurhila (1996) osutab, et argikõnedes on raskem 
määrata lõpetussegmendi algust ning neis viidatakse alati järgmisele kontaktile.

Kui telefonivestluste sissejuhatusi on palju uuritud Euroopa maades (Holland, Kreeka, Inglismaa, Šveits, Saksamaa, Rootsi, Soome, Eesti), siis lõpetussegmendi ülesehitusega seotud kontekstuaalseid tegureid on esile toodud eelkõige Eesti kultuuriruumist kaugete kultuuride puhul (Ecuador, Hiina, Jaapan, Ladina-Ameerika). Võib oletada, et samad tegurid mängivad rolli ka eesti telefonikõnede lõpetamisel. Käesolevas artiklis vaadeldaksegi, kuidas lõpetussegmendis kasutatavad keelelised vahendid on seotud osalejate vanuse, soo, suhete ja sotsiaalsete rollidega, kontaktide sagedusega ning vestlustüübiga.

\section{Materjal}

Analüüsi aluseks on 209 argitelefonikõnet Tartu Ülikooli suulise eesti keele korpusest. Kõned on salvestatud aastail 1997-2010. Omavahel suhtlevad pereliikmed, sugulased, sõbrad ja tuttavad (kolleegid, ülikooli- ja huviringikaaslased). Osalejaid on 215 vanuses 2-85 aastat, neist 74 meest ja 141 naist (vt tabel 1).

Tabel 1. Osalejate vanusegrupid

\begin{tabular}{|l|c|c|c|}
\hline Vanus aastates & Mehed & Naised & Kokku \\
\hline 2-10 (lapsed) & 3 & 4 & 7 \\
\hline $11-18$ (teismelised) & 11 & 20 & 31 \\
\hline 19-35 (noored täiskasvanud) & 39 & 56 & 95 \\
\hline 36-50 (keskealised) & 14 & 30 & 44 \\
\hline 51-65 (vanemad) & 5 & 19 & 24 \\
\hline üle 65 (eakad) & 2 & 12 & 14 \\
\hline Kokku & 74 & 141 & 215 \\
\hline
\end{tabular}

Kuna suulise keele korpus ei ole sotsiolingvistilises mõttes tasakaalus, siis ei ole seda ka argitelefonikõnede korpus. Korpuse koostamisel on püütud kaasata ja tasakaalustada erinevaid gruppe, kuid siiski on ülekaalus noorte naiste vestlused, kõige vähem on esindatud vanemad mehed. Samas esindab korpus kõiki vanuserühmi. 
Analüüsi keskmes on 140 lauatelefonikõnet. 25 kõne puhul kasutab üks osaleja lauatelefoni ja teine mobiili, mobiililt mobiilile kõnesid on 38 . Telefoni tüüp pole teada 6 juhul.

171 telefonikõnes on kaks osalejat, 38 telefonikõnes kolm või rohkem osalejat ning need kõned koosnevad mitmest dialoogist. Kokku oli analüüsitavas materjalis 331 lõpetussegmenti, millest 217 juhul vestlus lõpetati ning 114 segmenti jäeti pooleli. 46 vestluses oli kaks, 19 vestluses kolm, 4 vestluses neli, 2 vestluses viis ja 2 vestluses kuus lõpetussegmenti.

Analüüsitud korpuses on 118 infovestlust, 47 suhtehoidmisvestlust ja 43 vestlust, mille jooksul suhtlustüüp muutub. Suhtlustüübi muutuse puhul läheb infovestlus peaaegu alati üle suhtehoidmisvestluseks: kui info on edastatud või saadud, lobisetakse veel igapäevastel teemadel; vastupidise suhtlustüübi muutuse kohta on vaid kolm näidet. Sellest liigitusest jääb välja 9 dialoogi, milles küsiti ainult kedagi teist ega suheldud pikemalt.

Meeste ja poiste omavaheliste vestluste eesmärk on peaaegu alati info vahetamine, kusjuures pooled vestlused kestavad alla minuti. Naistel ja tüdrukutel on suhtehoidmisvestlusi veidi enam kui infovestlusi ning vestlused on tunduvalt pikemad.

Vestlused on transkribeeritud vestlusanalüüsi transkriptsiooni kasutades (vt Hennoste 2000a), transkriptsioonimärgid on esitatud artikli lõpus.

TÜ suulise eesti keele korpuse iga teksti juurde kuulub taustakirjeldus (vt Hennoste 2000a), milles on antud tehniline info salvestamise ja litereerimise kohta, situatsiooni kirjeldus, andmed suhtlejate kohta, vestluse ainestik, teema jm. Käesolevas töös on kasutatud infot suhtlussituatsiooni ning suhtlejate omaduste (sugu, vanus) ja nende omavaheliste suhete kohta.

Materjali analüüsitakse nii kvalitatiivselt kui ka kvantitatiivselt.

\section{Lõpetussegmendi ülesehitus eesti argitelefonivestlustes}

Eesti argitelefonivestluste lõpetussegment koosneb kolmest osast, mis on enamasti üles ehitatud naabruspaaridena või pikemate sekventsidena.

1. Esimene osa on lõpumärguanne + reaktsioon (noh, olgu 'nii. $\ddot{a} \ddot{a}=k \ddot{u l l}$.).

2. Sellele võib järgneda vaheosa, milles sooritatakse järgmisi tegevusi (analüüsitud materjali põhjal):

- korratakse varasemat kokkulepet või plaani (kule 'omme 'kõlla= sis, ma püian ise ka sealt poest 'läbi käia, vaatan mis ’räägivad. - no oleme 'rääkind.), 
- tehakse vestlusest kokkuvõte (nüd ma olen sis ära rääkind nüd $=$ on $=$ sis),

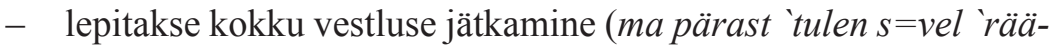
gib. - davai.),

- väljendatakse soovi uuesti suhelda ('näeme ja 'kuuleme äkki. jah.),

- antakse vestlusele hinnang (väga 'kena oli vahepeal 'lobiseda.),

- soovitakse head ('olge sis ‘ublid=ja (.) ja ‘saage ‘terveks. - nojah, te ise 'kah olge 'tublid sis.),

- saadetakse teistele tervitusi (tervita 'kõiki keda 'mina tean ja:.: kes 'mind teavad=ja (.) kõiki. $=h-o: k e i . o: k e i$.$) ,$

- tänatakse (aitäh. - noh võta 'eaks.),

- küsitakse vestluskaaslase nõusolekut vestluse lõpetamiseks ( ‘õ̃ik vist jah? - mhmh),

- viidatakse sellele, et helistamine on kallis (nojah ma arvan $=e t$ sul akkab mhemhe .hhhhh tulema mõnus 'arve. - noo las ta 'tuleb.),

- antakse mingi soovitus (tee `mämmi nüd lastele $=j a-j a h$ ),

- räägitakse oma järgmisest tegevusest (no ma olen `ikka nü̈̈d ma pean 'minema (0.5) õõo kule kell kümme tehakse ’pood ’ahti=näed, tolle `ä̈dile peab ‘saia ja Yeiba viima.).

Vaheosa tegevused jagunevad üldjoontes kaheks: info vahetamine (kokkuleppe kordamine, vestluse jätkamise kokkuleppimine) ja suhte alalhoidmine (nt tervituste saatmine, soovi avaldamine uuesti suhelda).

3. Vestlus lõpeb hüvastijättude vahetamisega (no tšauka. - no tšau).

Analüüsitud materjalis tuli esile nende osade kaheksa kombinatsiooni:

- ainult lõpumärguandesekvents (20 näidet),

- lõpumärguandesekvents + vaheosa (8 näidet),

- lõpumärguandesekvents + vaheosa + hüvastijätud (62 näidet),

- lõpumärguandesekvents + hüvastijätud (83 näidet),

- ainult hüvastijätud (13 näidet),

- lõpumärguanne ja hüvastijätt samas voorus (27 näidet),

- hüvastijätud + vaheosa + hüvastijätud (2 näidet),

- lõpumärguanne ja hüvastijätt samas voorus + vaheosa + hüvastijätud (2 näidet).

Lõpetussegmendi pikkus varieerub ühest voorust kuue sekventsini. 
Näites 1 on venna (H) ja õe (V) vestluse lõpetussegment.

(1) $1 . \mathrm{V}$ : vot. $=\mathrm{h}($.) no=e-e nii=et `ma siis `elistan $\mathrm{ku}=$ ma akkan `sinnapoole 2. `liikuma=või (0.4) või järsku `keegi `sõidab või `kuskile

3. `sinnakanti $=\mathrm{ja}=\mathrm{eks}=$ siss: eks=sis võtame ${ }^{\prime}$ ühendust.

4. (.)

5. H: noh, (.) anna `mär[ku.]

6. V:

[jah] (0.3) noh, olge=sis `terved $=\mathrm{ja}$

7. $(0.3)$

8. H: teie ka?

9. $(0.5)$

10. V: `tervita=sis `lapsi=ja `Lead minu poolt=ja

11. (0.3)

12. H: nnn sama `siitpoolt `teile $=[$ sis. $]$ hhhh

13. V: [jaa,]

14. V: jaa, (.) 'jõudu teile sis kõigile=ja

15. (.)

16. H: okei.

17. $(0.5)$

18. V: [no] `olgu. (.) [kõi]ke `hääd=sis.

19. H: [ťš-]

[tš-]

20. H: tšau. .nhhhh

V algatab lõpetamise kokkuleppe kordamisega (read 1-3), mis on tüüpiline lõpumärguanne. Lausung algab keelendiga nii et, mis alustab eesti keeles tihti kokkuvõtet ja ühtlasi uut vestlusfaasi (vt Keevallik 2000). eks=sis võtame '̈̈hendust viitab tulevasele tegevusele väljaspool käimas olevat vestlust. 5. real nõustub H ettepanekuga ning 6. real lõpetab V lõpumärguandesekventsi partikliga jah. Järgneb vaheosa (read 6-18), mille esimene järjend on soovimine ja vastusoovimine 6.-8. real. 10. real saadab V pereliikmetele tervitusi, 12. real vastab H samaga. Sekvents lõpetatakse partiklitega jaa, jaa 13.-14. real. 14.-18. real esitab V jälle soovid: ‘jõudu teile sis kõigile=ja; kõike `hääd=sis. 19. real püüab H alustada hüvastijättu. Vestlus lõpeb H hüvastijätuga $t \check{s} a u$, mis jääb vastuseta. 


\section{Lõpumärguanded}

Selles osas vaadeldakse kõigepealt eri tüüpi lõpumärguandeid, seejärel käsitletakse lõpumärguande positsioonis kasutatavaid hüvastijätte ning lõpuks mitmeosalisi lõpumärguandevoore.

\subsection{Implitsiitsed lõpumärguanded}

Implitsiitsed lõpumärguanded jagunevad kaheks: lühivariandid ja pikemad variandid.

Lühivariantidest on analüüsitud materjalis kesksed hea/hää/ää küll (74 korda) ja okei (65; vt näide 2); vähem kasutatud on olgu (24), selge (20), ega (siis muud) midagi (18), tavai (10), nii (8); muud üksikud näited: teeme nii (4), mis siis ikka (2), hüva (2), tore (2), kena (2), noh (2), hästi (1), okidoki (1), oolrait (1), eks siis näeb (1).

Pikemad implitsiitsed lõpumärguanded on kokkulepped, kokkuvõtted, soovivormelid, tervituse saatmised ja tänuavaldused.

Kesksed on nende hulgas kokkulepped. Lõpumärguandena kasutatavaid kokkuleppeid on kolme tüüpi.

Esiteks korratakse varasemat kokkulepet või plaani edasise tegevuse kohta (37 näidet; vt näide 1): .hh> aga 'minu juures < kell 'kolm kolmandal; sa sis 'anna ned 'allkirjad ’ära ja anna paber emmega kaasa. Vana materjali sissetoomine võib näidata, et võimalikud uued vestluse teemad on ammendatud (Liddicoat 2007: 265).

Teiseks osutatakse, et praegune vestlus jääb pooleli ning öeldakse konkreetselt, millal seda jätkatakse (8 näidet): ma `õhtul ’elistan sis mis ma sulle 'kaasa `panen jah?; no=kule mul on `tunne=et ma elistan sulle 'minuti pärast 'tagasi; $a=m a$ 'räägin sulle ’lähemalt, $k u=m a$ 'üles tulen.

Kolmandaks räägitakse üldsõnaliselt järgmisest helistamisest või kohtumisest, väljendatakse soovi uuesti suhelda, aga midagi konkreetset kokku ei lepita (16 näidet): noh, (.) 'varsti nääme =sis; ma 'elistan sis; 'elista 'koju ka vahel kuule; ‘teinekord 'räägime=sis jälle.

Kokkulepe loob seose praeguse ja tulevase vestluse vahel ja on sel viisil orienteeritud sotsiaalsete suhete hoidmisele (Liddicoat 2007: 262). Kokkulepe väljendab, et järgmine kontakt osalejate vahel on korrapärane, mitte juhuslik, ja näitab, et järgmist kohtumist soovitakse ja oodatakse (Button 1991). Teiseks võimaldavad kokkulepped praeguse vestluse 
lõpetada, pannes ette, et järgmisi võimalikke teemasid võidakse arutada järgmine kord (Button 1987).

Kokkuvõte osutab vestluse piiritlemisele, seda võidakse tõlgendada kui ettepanekut vestlus lõpetada. Kokkuvõtete kasutamise kohta lõpumärguandena on 9 näidet. Tavaliselt tehakse kokkuvõte kogu vestlusest (no 'nii=et=hhhhh (0.4) et (0.4) ma arvan=et=hhh midagi 'oskasin ’öelda.), lõpetamisele võib viia aga ka käsiloleva teema kokkuvõte (igal=juhul ma ootan pikisilmi seda tulevat nädalat.).

Soovivormeliga ('olge $=$ sis `tublid; 'lõbutse siis; ead `isu ‘sulle) või tervituse saatmisega ( tervita =sis teisi $k a$; kule 'patsuta oma ’papagoisid $s i s=j a$ ) algatati lõpetamine vastavalt 15 ja 7 korda. Nendega minnakse käimas oleva vestluse teemadest välja, võidakse osutada partneri järgmisele tegevusele, mis toimub pärast vestluse lõppu.

Tänamist kasutati lõpetamise algatamiseks 17 korda. Valdavalt tänatakse saadud info eest (kule 'Virve ma väga ‘ünan sind selle info eest; lühikestes infovestlustes aitäh), paaris vestluses ka helistamise eest (aitäh=et (0.6) 'helistasid).

Kokkuleppeid, kokkuvõtteid ja tänuavaldusi esineb ka vestluse sees. Siin on vaadeldud ainult selliseid juhtumeid, kui osalejad tõlgendavad neid lõpumärguandena.

\subsection{Eksplitsiitsed lõpumärguanded}

Eksplitsiitsed lõpumärguanded lähtuvad kõnelejast endast, vestluskaaslasest või kellestki kolmandast sisse toodud isikust.

Kõnelejast lähtuvad märguanded on järgmised.

Kõneleja teeb otsese ettepaneku vestlus lõpetada (5 näidet): lõpetame; 'lõpetame siis ‘ära; kule ‘aitab nüüd; tead, (.) ’äkki me ’rohkem ei ‘äägi; kule=ma 'lõpetan siis ‘ära.

Kõneleja annab teada, et tal ei ole enam millestki rääkida (15 näidet): $a=k u l e=e g a=m a=$ sis noh, ei= 'oskagi midagi; $m a=i$ 'oskagi muud; $<$ e:ga 'miskit 'muud ma:...: praegu 'ei > 'tahtnud. Sellega viidatakse teemade ammendumisele.

Ma lähen-tüüpi teated, millele võidakse lisada ka järgmine tegevus (8 näidet): ea=kül ma lähen; kuule olgu, ma lähen siis teen kartuliputru ja; no=nii ma ’ähen e lektriku ’järgi. Järgmisest tegevusest võib olla varem juttu olnud või tuuakse see alles nüüd sisse. Seda tüüpi teated on 
eri tugevusega: nõrgemal juhul järgmist tegevust ei nimetata, kule ma pean `ö̈öki=minema $m u l=o n$ seal 'liha osutab aga möödapääsmatule vajadusele vestlus kohe lõpetada.

Vestluskaaslasest lähtuvad järgmised lõpumärguanded.

Küsitakse vestluskaaslase nõusolekut lõpetada (20 näidet): präegu sis `kõik sis jah; ’kõik=vä; ’praegu nagu `räägitud nüd=võ. Eraldi alarühma moodustavad eeldused, et vestluskaaslasel enam uudiseid ei ole ('sul ei=ole=vist 'nii ruttu mit- 'mingit undiseid jah; mund 'eriti ei ole sis `jah). Need on vormistatud kinnitust ootava küsimusena, mille lõpus on partikkel jah või $e k s j u$. Niisugused lõpumärguanded osutavad teemade ammendumisele.

Antakse hinnang oma helistamisele või pikaksveninud kõnele kui vestluskaaslast segavale või tüütavale tegevusele (6 näidet): $m a=i=$ 'akka sind 'kiusama; ma sul sis 'rohkem ‘ööd ei 'sega; ma jätan $s u$ 'rahule nüd=sis; 'ma=ei 'sega sind sis enam. (0.4) 'lobisemisega.

Kui vestluse käigus on selgunud, millega vestluskaaslane enne telefonikõnet tegeles, pakutakse võimalust varasema tegevuse juurde tagasi pöörduda (5 näidet): ‘akkad sis ‘ööle jah; ma ’lasen sul sis ‘duši alla minna =et; kas sa lähed sis nü̈̈d ’mängima `tagasi.

Omaette rühma moodustavad vastaja viited sellele, et helistamine on kallis (8 näidet): sul läheb 'kalliks; ära `raiska 'raha; ah `sina `elistad `vabandust sinu 'raha 'läheb; kule lapsekene ma ära ’raiska oma ’raha rohkem.

Kolmandal juhul osutatakse kellelegi juuresolijale, kes sunnib vestlust lõpetama (4 näidet): kule `need räägivad Tommi ja Terri ‘akkavad sis ma pean varsti 'lópetama; nüüd ta ‘ajab mind siit välja kule). Selle võttega pehmendatakse lõpetamist, veeretades ,süü” teisele.

Sellesse rühma kuuluvad ka viited tehnilistele probleemidele: mobiilikõnedes hoiatatakse, et aku saab tühjaks (2 näidet): mul saab ‘aku ka ‘ühjaks kohe.; mul akkab ‘aku ‘ühjaks saama, varsti ’katkeb. Erinevalt teistest algavad mõlemad sellised märguanded pealerääkimisega teise osaleja vooru ajal. Ennetatakse seda, et kõne katkemist võib vestluskaaslane tõlgendada soovimatusena edasi rääkida.

Kokkuvõttes näeme, et lühimärguanded osutavad piirile vestluses, pikemad lõpumärguanded (nii implitsiitsed kui ka eksplitsiitsed) on aga üldjoontes kaht tüüpi: ühed osutavad teemade ammendumisele, teised aga viivad dialoogist välja: räägitakse sellest, mis toimub pärast kõne lõppu. 


\subsection{Hüvastijätud lõpumärguande positsioonis}

Hüvastijätud on tavaliselt vestluse viimane sekvents (Schegloff, Sacks 1973), millele eelneb lõpumärguanne ja selle aktsepteerimine.

Selle kõrval on ka niisuguseid lõpetusi, kus kõneleja lisab lõpumärguandele samas voorus kohe hüvastijätu (nt no=okei=noh='tšau.; 36 näidet). Sel juhul ei oota ta lõpumärguandele reaktsiooni. 16 vestluses jäeti lõpumärguanne ära ning esitati kohe hüvastijätt. Mõlemad kasutused viitavad soovile vestlus kohe lõpetada vestluskaaslase nõusolekut ootamata. Püütakse välistada võimalus lõpetussegment katkestada, kuna hüvastijätt kui naabruspaari esiliige ootab järelliikmeks samuti hüvastijättu (vt Button 1987: 135-137). Enamik lõpumärguande positsioonis hüvastijätte tuleb esile lühikestes infovestlustes, mille helistaja lõpetab kohe, kui on vajaliku info saanud või edastanud (vt näide 2 ). Hüvastijättu võidakse kasutada ka ebameeldiva või liiga pikaks veninud vestluse lõpetamiseks.

\subsection{Mitmeosalised lõpumärguanded}

Sageli esitatakse samas voorus järjest mitu lõpumärguannet, millele võib lisanduda veel hüvastijätt. Analüüsitud vestlustes koosneb ühest komponendist 202, mitmest 129 lõpumärguandevooru. Eesti vestlustes on üldine tendents, et liigutakse nõrgemalt vahendilt tugevama poole (lühimärguanne $>$ pikem implitsiitne märguanne $>$ eksplitsiitne märguanne), hüvastijätt on peaaegu alati vooru lõpus. Peamiselt tulevad esile kaheosalised järjendid, näiteks okei, samal ‘ajal siis 'kohtume. ; kuule olgu, ma lähen siis teen kartuliputru ja.

Materjali hulgas on ka mõned kolmeosalised järjendid, näiteks hea=`küll, me 'tuleme õhtul 'sinna, ma sul sis ‘rohkem `tööd ei \$ `sega. $=h h h \$$. Voor algab lühimärguandega hea = küll, millele järgneb implitsiitne märguanne me 'tuleme õhtul 'sinna, ning voor lõpeb eksplitsiitse märguandega ma sul sis ‘rohkem ‘ööd ei \$ `sega. $=$ hhh \$.

Siiski on ka näiteid (kokku 9), kus enne kasutatakse tugevamat ja seejärel nõrgemat vahendit: aga okei ‘šau, ‘mõnikord saame ’kokku ja ‘äägime.; ' lõpetame siis ‘ära. 'elista `koju ka vahel kuule. Valdavalt on sel juhul vooru lõpus viide järgmisele kontaktile, millega pehmendatakse käesoleva vestluse lõpetamist. 


\section{Lõpumärguande tüübi ja keelelise vormistuse valiku seletused}

Lõpumärguanded jagunevad keeleliselt vormistuselt kahte rühma: osa on suhteliselt püsivad vormelid, teised mitte. Vormeleid on üsna vähe: lühimärguanded (hea küll; ega midagi), tänuavaldused (aitäh; suur tänu sulle), osa sooviavaldusi uuesti suhelda (varsti näeme; ma helistan sis; teinekord räägime), enamik soove (ole sis tubli / olge sis tublid; hoidke ennast; ela hästi; head aastavahetust), osa tervitusi (tervita NIMI / teisi ka / kõiki), mõni eksplitsiitne lõpumärguanne (ma ei oskagi muud/midagi; ma lähen). Enamik pikemaid lõpumärguandeid on „siin ja praegu” moodustatud laused, kõik on eri viisil vormistatud ning konkreetseid keelelisi vahendeid ei saa nimetada.

Lõpumärguannetes kasutatakse palju partikleid no, noh, kule/kuule, sis/siis, harvem a/aga, tead, nojah, vat. Ilma nende partikliteta on ainult veerand lõpumärguannetest. Sageli kasutatakse mitut partiklit koos ( no=kule $\ddot{a}=$ 'küll=sis= $\ddot{a}$; noh, kuule ega ega 'midagi; aga okei no 'tšau pärast `n̈̈eme). Partiklit kule on kirjeldatud kui vooru alguses paiknevat piiripartiklit (Hennoste 2000b: 1801; 2000c: 2468-2469). Leelo Keevallik (2003: 59-60; 2005: 544) osutab, et kule projitseerib järgmist tegevusfaasi, sh vestluse lõpetamist, ning kollokatsioonil no kule on tugevam liigendav funktsioon kui ainult partiklil kule. Ka partiklite no ja noh üks funktsioone on vestlusteema üleminekule osutamine (Hennoste 2000b: 1802; 2001: 188). Partiklite kasutust käesolevas artiklis lähemalt ei käsitleta.

Sotsiaalsete tegurite mõju tuleb esile eeskätt selles, kas valitakse lühike või pikem märguanne. Käsitletakse ka seda, missuguste teguritega on seotud lühimärguandena kasutatava sõna valik. Pikemate märguannete tüübi valikul ei moodustu selgeid sotsiaalseid gruppe, mõne tüübi kohta on ka liiga vähe näiteid.

\section{Vanus}

Laste ja teismeliste omavahelistele vestlustele on iseloomulik see, et lõpetussegmendi esimeses voorus esitatakse kohe hüvastijätt: kas lõpumärguande järel või ilma lõpumärguandeta ( $2 / 3$ juhtudest). Sellele vastatakse samuti hüvastijätuga või ei vastata üldse. Kui vestluskaaslane on vanem, kasutatakse pikemaid lõpumärguandeid veidi enam, kuid ülekaalus on siiski lühimärguanded. 
Näite 2 ridadel 4-6 on tüüpiline teismeliste vestluse lõpusegment. Räägivad 11- ja 13-aastane poiss.

(2) $1 . \mathrm{H}$ : sis=ma elistan `sulle=vä.

2. $(0.7)$

3. V: ei ma `tean, kuna `Kark `tuleb.

4. $\mathrm{H}$ : aa, no $=$ okei tšau.

5. $(0.4)$

6. V: tšau.

Keskealised kasutavad omavahel ja noorema inimesega vesteldes lühikesi ja pikemaid märguandeid enam-vähem ühepalju. Vanema vestluskaaslase korral on aga lühimärguandeid $1 / 3$ ja pikemaid märguandeid 2/3. Vanemad ja eakad inimesed kasutavad peaaegu alati pikemaid lõpumärguandeid.

Seega on näha, et noored kasutavad lühimärguandeid palju rohkem kui vanemad. Lõpumärguande tüübi valik oleneb ka vestluskaaslasest: vanema inimesega rääkides kasutatakse pikemaid lõpumärguandeid enam kui eakaaslasega või endast nooremaga vesteldes.

Ühe- ja mitmeosaliste lõpumärguandevoorude kasutust võrreldes ilmneb, et kõikides vanusegruppides on üheosalisi veidi rohkem. Mitmeosalised voorud on kaht tüüpi:

- teine osa on hüvastijätt, mis viitab soovile vestlus kiiresti lõpetada,

- teine osa on info vahetamiseks (ma panen 'riidesse akkan 'tulema.) või suhte hoidmiseks (näeme siss).

Missugune tegevus vooru lõpus sooritatakse, see on suurel määral seotud osaleja vanusega. Noored lõpetavad vooru enamasti hüvastijätuga, vanemad eelistavad infole või suhtele suunatud tegevusi.

Lühimärguannetest on lastel ja teismelistel kasutusel peaaegu ainult okei (86\%), muid vormeleid (tavai, hea küll, ega midagi, olgu, hüva) on tarvitatud vaid üks kord. Mida vanemate osalejatega on tegu, seda vähem okei'd kasutatakse: vanusegruppides 19-50 esineb seda 23\%, vanematel puudub, eakatel üks kord. Täiskasvanutel on kõige sagedasemaks lõpumärguandeks hea küll, sellele järgnevad selge ja olgu.

\section{Sugu}

Naised kasutavad pikemaid ja mitmeosalisi lõpumärguandeid veidi rohkem kui mehed. Olulisim erinevus ilmneb mitmeosaliste märguandevoorude kasutuses: meestel on viimaseks komponendiks hüvastijätt 55\% juhtudel, naistel $23 \%$ juhtudel. 
Sõnavalikus märkimisväärseid erinevusi ei ilmnenud. Nii meestel kui ka naistel on kesksed okei ja hea küll.

\section{Osalejate suhted ja kontaktide sagedus}

Esile tuli kaks rühma. Skaala ühe otsa moodustavad pereliikmed ja sõbrad, kes kasutavad lõpetamise algatamiseks peamiselt lühimärguandeid ja hüvastijätte. Eraldi elavad pereliikmed ja kaugemad sugulased kasutavad pigem pikemaid lõpumärguandeid. Muud rühmad (õed-vennad, tuttavad) on heterogeensed.

See on korrelatsioonis suhtlemise sagedusega: kui kohtutakse (peaaegu) iga päev, kasutatakse pigem lühikesi lõpumärguandeid. Harvemate kontaktide korral eelistatakse pikemaid märguandeid.

\section{Vestlustüüp}

Lühimärguanded ja kokkuleppe kordamine on iseloomulikumad infovestlustele. Suhtehoidmisvestlustes eelistatakse muid pikemaid lõpumärguandeid. Kui infovestlus läheb üle suhtehoidmisvestluseks, kasutatakse lõpetamisel pigem infovestlusele omaseid võtteid: lühimärguandeid on rohkem kui suhtehoidmisvestlustes ning sageli pöördutakse lõpetades infoosa juurde tagasi, korratakse vestluse esimeses osas sõlmitud kokkulepet, tehakse saadud infost kokkuvõte või tänatakse info eest. See võib osutada sellele, et esmane vestlustüübi määratus on olulisem.

Infovestlustes kasutatakse üheosalisi lõpumärguandeid enam kui suhtehoidmisvestlustes. Mitmeosalise märguandevooru teine osa on infovestlustes tavaliselt hüvastijätt või kokkuleppe kordamine, suhtehoidmisvestlustes muu pikem lõpumärguanne.

Okei ja hea küll jaotuvad info- ja suhtehoidmisvestlustes erinevalt. Infovestlustes on esikohal okei (33\%), talle järgneb hea küll (22\%). Suhtehoidmisvestlustes domineerib hea küll (44\%), okei on teisel kohal (23\%). Info vastuvõtmist või kokkuleppele jõudmist markeeriv selge esineb peaaegu ainult infovestlustes.

\section{Kokkuvõtteks}

Lühimärguanded on iseloomulikud pigem noortele, sõpradele ja pereliikmetele ning esinevad ennekõike sagedaste kontaktide puhul ja infovestlustes. Pikemaid märguandeid kasutavad pigem vanemad inimesed, 
harvemini kohtuvad sugulased, eeskätt suhtehoidmisvestlustes. Eri tegurid kombineeruvad omavahel: näiteks on teismelised omavahel sõbrad, kes kohtuvad sageli ja suhtlevad peamiselt info vahetamiseks; vanemad ja eakad suhtlevad eeskätt sugulastega ning vestluse eesmärk on suhte hoidmine jne.

Lühimärguandena kasutatava sõna valikul mängib kõige suuremat rolli vanus. Okei on iseloomulik eelkõige lastele ja teismelistele, vanematel inimestel see peaaegu puudub, neil domineerib hea küll. Selge on omane eelkõige infovestlustele.

\section{Hüvastijätud}

Hüvastijättude puhul on tegu vormelitega. Need jagunevad kahte rühma: osa on neutraalsed, osa argised (neid ei kasutata institutsionaalses suhtluses). Neutraalsesse rühma kuuluvad head aega, head/hüva õhtut, nägemist/ nägemiseni, kohtumiseni, homseni, kuulmiseni, õhtuni. Argised on adaa/ aidaa/adah/aidah/tadaa/taidaa, tšau, tšauka/tšauki, hüva, nägudeni, pakaa. Tšau erineb teistest, kuna on kasutusel ka tervitusena. Fulvio Meguschari (2004) hinnangul on ciao eesti keelde tulnud ajavahemikul 1950-1970 Itaalia filmide või laulude kaudu. Sõna pragmaatiline tähendus eesti keeles ei erine oluliselt algupärandi omast, sest ka itaalia sõnaraamatud esitavad ciao põhiliselt hüvastijätusõnana, kuigi itaalia keeles kasutatakse seda ka tervitusena.

Samamoodi nagu lõpumärguannete puhul, eelneb või järgneb ka hüvastijätule sageli partikkel. Kõige sagedasem on no (87 korda), kasutatud on ka partikleid noh (31 korda), siis/sis (23 korda), kule (1 kord). No eelneb tavaliselt sõnale tšau (esiliikmele) ja on sellega kokku hääldatud, moodustades intonatsioonilise terviku $(n o=t \check{s} a u)$. Järelliikmele enamasti partiklit ei eelne (no=tšau - tšau). Partiklid kaasnevad eelkõige argiste hüvastijättudega, neutraalsete puhul kasutatakse neid harva. Kõik kümme vormelit head aega olid ilma partiklita, nägemist/nägemiseni $4 / 5$ juhtudel ilma partiklita, vormeliga head õhtut kaasnes mõnikord partikkel siis + saatelause (’präegu ma soovin sulle sis ead `ôhtut.; üva `õhtut siis ütleme nii.). Üks partiklite funktsioon näib seega olevat sotsiaalse läheduse märkimine ja lõpetamise pehmendamine.

Hüvastijätud esinevad enamasti naabruspaaridena. Tüüpiliselt vastatakse sama sõnaga (116 näidet) või neutraalsuse-argisuse skaalal sama 
tasandi sõnaga, nt head aega-nägemist; adah-tšau (24 näidet). Vähestel juhtudel on teine hüvastijätt esimesest argisem (head aega - tšau) või ametlikum (adah - nägemist), kummagi kohta on 7 näidet. Reageerida võidakse ka partikliga $m h m h, m h, j a h$, noo (13 näidet $\left.{ }^{2}\right)$.

Vastuhüvastijätt puudub 27 näites. Reaktsiooni puudumise põhjusi pole sageli võimalik ei teksti ega taustainfo põhjal seletada. Osa näiteid selgitab asjaolu, et vestluse lõpus lepitakse kokku varsti uuesti kohtuda või helistada: kuna suhtlus jätkub peagi, ei jäeta vahepeal hüvasti. Maria Placencia (1997) on eksplitsiitsete hüvastijättude puudumist seletanud nende asemel kasutatavate väljendite (nt tänamine) polüfunktsionaalsusega.

\section{Hüvastijättude keelelise vormistuse valiku seletused}

Järgnevalt vaadeldakse, millega on seotud hüvastijätuvormeli valik.

\section{Vanus}

Tšau on omane eelkõige noorematele suhtlejatele (kuni 18-aastastel 86\% hüvastijättudest). Vanemad inimesed kasutavad seda vähe ning eeskätt järelliikmena, vastuseks kaasvestleja tšau'le. Hüva tuleb enim esile keskealistel ja vanematel. Eakate puhul domineerib nägemist. Pakaa'd (4 näidet) kasutavad keskealised ja vanemad suhtlejad - tegu on jäänukiga nõukogude ajast, mida nooremad pole omandanud.

\section{Sugu}

Ainus erinevus on adah-sarja kasutamisel: naised 20 korda, mees 1 kord (+ üks kolmeaastane poiss). Tegu on lastekeele sõnadega, mis on kasutusel eeskätt pereringis. Ainuke mehe adah oli järelliikmeks tädi öeldud adah'ile.

\section{Osalejate suhted}

Nagu võiski eeldada, kasutavad lähedased rohkem argiseid hüvastijätuvormeleid kui tuttavad (kolleegid, ülikooli- ja huviringikaaslased, sõbra ema). Lähedastel on argiseid vormeleid $86 \%$, tuttavatel $60 \%$.

2 Naabruspaari hüva=jah / $m h m h$ kasutas üks suhtlejatepaar 7 vestluses, ülejäänud näited on eri osalejatelt. 


\section{Vestlustüüp}

Info- ja suhtehoidmisvestlustes erineb eelkõige sõna tšau kasutus, mis moodustab infovestlustes $75 \%$, suhtehoidmisvestlustes $51 \%$ hüvastijättudest. Üks niisuguse kasutuse seletus võib olla seos osalejate vanusega: vanemad inimesed, kes tšau'd vähem kasutavad, vestlevad eelkõige suhte hoidmise eesmärgil.

\section{Argiste ja institutsionaalsete telefonivestluste lõpetamise võrdlus}

Võrdluse aluseks on institutsionaalsete telefonikõnede lõpetussegmendi kaht esimest vooru käsitlev artikkel (Rääbis 2002). Selle uurimuse materjaliks oli 85 telefonikõnet: 48 korral helistati infotelefonile, 37 korral mingisse ettevõttesse või ametiasutusse (nt bussijaam, reisibüroo, ehitusfirma, polikliinik, kauplus, autoremonditöökoda, sotsiaalabi osakond). Analüüsiti helistaja algatatud lõpetamisi, mida oli kokku 84.

Kõige sagedasem lühimärguanne oli analüüsitud institutsionaalsetes kõnedes sõna selge (35 korda), hästi esines kolmel korral ja kena kahel korral. Siin saab paralleeli tõmmata argiste infovestlustega, kus selge markeerib samuti info vastuvõtmist või kokkuleppele jõudmist. Suhtehoidmisvestlustes selge sama hästi kui puudub.

Teine lõpualgatuse vahend institutsionaalses suhtluses on tänamine, mis sisaldus enamikus lõpetussegmenti alustavates voorudes, aga võib paikneda ka hilisemas voorus. Vastajat ei tänatud ainult ühes dialoogis, kuid tänamist asendas sel juhul soovivormel. Tänatakse ka siis, kui soovitud infot ei saadud. Argisuhtlusega võrreldes saab jällegi paralleeli tõmmata infovestlustega, kus info eest tänatakse, aga seda tehakse tunduvalt harvem kui institutsionaalses suhtluses. Suhtehoidmisvestlustes võidakse tänada helistamise eest.

Eksplitsiitseid lõpumärguandeid (no aitab; aitab ka vist) leidus kahes institutsionaalses dialoogis, kui helistaja ei soovinud rohkem infot.

Mitmeosalisi lõpumärguandevoore oli institutsionaalsetes telefonikõnedes veidi enam kui argistes. Samamoodi liigutakse nõrgemalt vahendilt tugevama poole (selge aitäh nägemist.).

Hüvastijätte oli institutsionaalsetes dialoogides märksa vähem kui argivestlustes (vastavalt $37 \%$ ja $87 \%$ vestlustes) ning need tulid esile eelkõige ettevõtetesse ja asutustesse (mitte infotelefonile) helistamisel. 
Infotelefoni kõnede lõpetussegment koosnes üldjuhul vaid kahest voorust: tänamine ja reaktsioon sellele.

Seega on näha, et argiste ja institutsionaalsete telefonikõnede lõpetamine erineb suurel määral nii lõpetussegmendi pikkuse, lõpumärguande tüübi kui sõnavaliku poolest. Esile tulevad mõned sarnasused argiste infovestlustega: lõpumärguanne selge ning info eest tänamine.

\section{Kokkuvõte}

Eesti argitelefonivestluste lõpetussegment koosneb kolmest osast: 1õpumärguanne ja reaktsioon sellele, vaheosa ning hüvastijätud. Käesolev artikkel keskendus lõpumärguannete ja hüvastijättude keelelisele vormistusele.

Telefonivestluste uurijad on toonud välja rea lõpetussegmendi ülesehitusega seotud kontekstuaalseid tegureid: vestlustüüp, osalejate vanus ja sugu, nende omavahelised suhted ja sotsiaalne distants, kontaktide sagedus, suhtluse argisus või institutsionaalsus. Hüpoteesiks oli, et need tegurid mängivad rolli ka eesti telefonivestluste lõpetamisel kasutatavate keeleliste vahendite valikul.

Esiteks vaadeldi seda, missuguseid keelelisi vahendeid lõpetamissoovi väljendamiseks kasutatakse. Lõpumärguandeid on kaht tüüpi: implitsiitsed ja eksplitsiitsed. Keeleliselt vormistuselt jagunevad lõpumärguanded kahte rühma: osa on vormelid, osa mitte. Erinevaid vormeleid on suhteliselt vähe (nt aitäh, varsti näeme, ole sis tubli, ela hästi, tervita teisi ka). Enamik pikemaid lõpumärguandeid on konkreetset vestluskaaslast ja olukorda arvestades moodustatud laused, mille keelelise vormistuse kohta on raske üldistusi teha. Seetõttu käsitleti artiklis ainult lühikese või pikema märguande ning lühimärguandena kasutatava sõna valikuga seotud tegureid.

Lapsed ja teismelised kasutavad enamjaolt lühimärguandeid (nendest omakorda domineerib okei), vanemad ja eakad peaaegu ainult pikemaid märguandeid. Üle 50-aastastel esineb okei ainult üks kord. Täiskasvanutel on sagedasemad lõpumärguanded hea küll, selge, olgu.

Kui ühes voorus esitatakse järjest mitu komponenti, lõpetavad lapsed ja teismelised vooru enamasti hüvastijätuga (okei tšau), vanemad mingi infot vahetava või suhet alalhoidva tegevusega (hea= küll. eks me siis 'arutame 'asja=vel.). Sama tendents ilmneb meeste ja naiste vestluste võrdluses: naised kasutavad pikemaid ja mitmeosalisi lõpumärguandeid veidi enam kui mehed; meestel lõpeb mitmeosalistest lõpumärguannetest 
hüvastijätuga üle poole, naistel umbes veerand. Konkreetse sõna valikul meeste ja naiste vahel olulist erinevust ei ole.

Rolli mängivad ka osalejate suhted ja kontaktide sagedus. Koos elavad või (peaaegu) iga päev kohtuvad pereliikmed ja sõbrad kasutavad peamiselt lühimärguandeid, eraldi elavad pereliikmed ja kaugemad sugulased pigem pikemaid lõpumärguandeid.

Infovestlustes kasutatakse lõpetamise algatamiseks enam lühimärguandeid ja kokkuleppe kordamist, suhtehoidmisvestlustes muid pikemaid lõpumärguandeid. Lühimärguannetest on infovestlustes esikohal okei, suhtehoidmisvestlustes hea küll. Selge on iseloomulik eelkõige infovestlustele.

Erinevalt lõpumärguannetest on hüvastijättude puhul tegu vormelitega, mis jagunevad kaheks: neutraalsed (head aega, nägemist, kohtumiseni) ja argised (adah, tšau, nägudeni, pakaa). Ka hüvastijätusõna valikul mängib rolli osaleja vanus: lapsed ja teismelised kasutavad peaaegu ainult tšau'd, mille osatähtsus vanematel inimestel on väiksem (üle 65-aastastel vaid üks näide). Eakatel prevaleerib nägemist ka lähedastega suheldes. Tšau domineerib infovestlustes (75\% hüvastijättudest), suhtehoidmisvestlustes on ťsau hüvastijätusõnaks pooltes näidetes. Sooline erinevus ilmneb adah-sarja kasutusel: ainus mehe adah oli järelliikmeks naise adah'ile.

Kuidas eri vahendid ja tegurid omavahel kombineeruvad? Esiteks võib välja tuua komplekti okei + tšau, mis on omane eelkõige noortele, sõpradele, sagedaste kontaktide puhul ning infovestlustele. Vanematel suhtlejatel niisugune kombinatsioon sama hästi kui puudub: eelistatakse pikemaid lõpumärguandeid ning neutraalsemaid hüvastijätusõnu.

Teiseks saab esile tuua eri tegurite kombinatsioonid, mis töötavad koos ja ühes suunas. Meeste omavaheliste vestluste eesmärk on peaaegu ainult info vahetamine. Naised peavad nii info- kui ka suhtehoidmisvestlusi, kusjuures viimaseid oli korpuses veidi enam.

Lapsed ja teismelised suhtlevad omavahel sageli, peamiselt info vahetamiseks, on sõbrad. Kõik need tegurid on seotud pigem lühimärguannete ja vestluse kiire lõpetamisega. Vanemad inimesed seevastu suhtlevad peamiselt sugulastega, kontaktid on harvemad, helistamise eesmärk on eelkõige suhte hoidmine. Lõpetamise algatamiseks kasutatakse sel juhul pikemaid märguandeid, lõpetussegment katkestatakse sageli ja pöördutakse teema juurde tagasi - kogu lõpetusprotsess on pikem.

Artiklis keskenduti lõpumärguande- ja hüvastijätusekventsidele. Edasi tuleks täpsema vaatluse alla võtta vaheosa tegevused ja nende keeleline 
vormistus. Teiseks näitas esmane analüüs, et umbes kolmandik lõpualgatusi ei viinud vestluse lõpetamisele. Lõpetussegmendi katkestamise põhjused ja viisid vajavad samuti analüüsimist.

Keeleühiskonnas ilmnevate suhtlusmudelite tuvastamine annab väärtuslikku infot eesti keele kui võõrkeele õpetamisel, aidates arendada keeleõppijate pragmaatilist pädevust.

\section{Transkriptsioonimärgid ja lühendid}

$\begin{array}{ll}\cdot & \text { langev intonatsioon } \\ \text { ? } & \text { poollangev intonatsioon } \\ \text { (.) } & \text { mõusev intonatsioon } \\ (0.5) & \text { pausi pikkus sekundites } \\ \text { sõna } & \text { rõhutamine } \\ {[\text { ] }} & \text { pealerääkimine } \\ = & \text { kahe iseseisva üksuse kokkuhääldamine } \\ <> & \text { aeglustatud lõik } \\ >< & \text { kiirendatud lõik } \\ \$ \$ & \text { naerev hääl } \\ \text { : } & \text { hääliku venitus } \\ - & \text { sõna poolelijäämine } \\ \text { hh } & \text { sissehingamine } \\ \text { hh } & \text { väljahingamine } \\ \text { mhemhe } & \text { naer } \\ \text { H } & \text { helistaja } \\ \text { V } & \text { vastaja }\end{array}$

\section{Kirjandus}

Brown, Penelope, Stephen Levinson 1987. Politeness. Some Universals in Language Usage. Cambridge: Cambridge University Press.

Button, Graham 1987. Moving out of closings. - Talk and Social Organization. Ed. Graham Button, John R. E. Lee. Clevedon: Multilingual Matters, 101-151.

Button, Graham 1991. Conversation-in-a-series. - Talk and Social Structure. Studies in Ethnomethodology and Conversation Analysis. Ed. Deirdre Boden, Donald H. Zimmerman. Cambridge: Polity Press, 251-277.

Coronel-Molina, Serafin M. 1998. Openings and closings in telephone conversations between native Spanish speakers. - Working Papers in Educational Linguistics 14 (1), 49-68. 
Drew, Paul, Kathy Chilton 2000. Calling just to keep in touch. Regular and habitualised telephone calls as an environment for small talk. - Small Talk. Ed. Joustine Coupland. London: Longman, 137-162.

Etehadieh, Elaheh 2011. Closings of Persian telephone conversation: A CA perspective. http://langfest.anu.edu.au/index.php/als/alaa-alanz/paper/ view/3261 (22.04.2014).

Hennoste, Tiit 2000a. Suulise eesti keele uurimine: transkriptsioon, taust ja korpus. - Keel ja Kirjandus 2, 91-106.

Hennoste, Tiit 2000b. Sissejuhatus suulisesse eesti keelde IV. Suulise kõne erisõnavara 3. Partiklid. - Akadeemia 8, 1773-1806.

Hennoste, Tiit 2000c. Sissejuhatus suulisesse eesti keelde VI. Lausung suulises kõnes 1. - Akadeemia 10, 2223-2254.

Hennoste, Tiit 2001. Sissejuhatus suulisesse eesti keelde IX. Lausung suulises kõnes 4. - Akadeemia 1, 179-206.

Hennoste, Tiit, Andriela Rääbis 2004. Dialoogiaktid eesti infodialoogides: tüpoloogia ja analüüs. Tartu: Tartu Ülikooli Kirjastus.

Kamimoto, Emiko 2010. You can't just hang up - Differences in Japanese family phone conversations. - Society for Gender Studies in Japanese annual convention 2010. http://www.gender.jp/journal/no11/12_kamimoto.html (22.04.2014).

Keevallik, Leelo 2000. Keelendid et ja nii et vestluses. - Keel ja Kirjandus 5, 344-358.

Keevallik, Leelo 2003. From Interaction to Grammar. Estonian Finite Verb Forms in Conversation. (= Acta Universitatis Upsaliensis. Studia Uralica Upsaliensia 34.) Uppsala.

Keevallik, Leelo 2005. Suhtluskeele uurimine partiklistunud verbivormide näitel. - Keel ja Kirjandus 7, 535-548; 8, 630-642.

Kurhila, Salla 1996. Puhelinkeskustelujen aloituksista ja lopetuksista. - Kakkoskieli 1. Toim. Salla Kurhila. Helsingin yliopiston suomen kielen laitos, 127-152.

Liddicoat, Anthony J. 2007. An Introduction to Conversation Analysis. New York: Continuum.

Meguschar, Fulvio 2004. Mõningaid tähelepanekuid sõnast tšau. - Keel ja Kirjandus 3, 213-215.

Pavlidou, Theodossia-Soula 1998. Greek and German telephone closings. Patterns of confirmation and agreement. - Pragmatics 8, 79-94.

Placencia, Maria Elena 1997. Opening up closings - the Ecuadorian way. - Text 17 (1), 53-81. http://dx.doi.org/10.1515/text.1.1997.17.1.53.

Rääbis, Andriela 2002. Ametlike telefonikõnede lõpetamine: kuidas helistaja lõpetamise algatab. - Emakeele Seltsi aastaraamat 47 (2001). Tallinn, $107-125$. 
Rääbis, Andriela 2009. Eesti telefonivestluste sissejuhatus: struktuur ja suhtlusfunktsioonid. (= Dissertationes linguisticae Universitatis Tartuensis 13.) Tartu: Tartu Ülikooli Kirjastus.

Schegloff, Emanuel A., Harvey Sacks 1973. Opening up closings. - Semiotica 8, 289-327. http://dx.doi.org/10.1515/semi.1973.8.4.289.

Sun, Hao 2005. Collaborative strategies in Chinese telephone conversation closings: balancing procedural needs and interpersonal meaning making. - Pragmatics 15 (1), 109-128.

Takami, Tomoko 2002. A study on closing sections of Japanese telephone conversations. - Working Papers in Educational Linguistics 18 (1), 67-85.

Andriela Rääbis

eesti ja üldkeeleteaduse instituut

Tartu Ülikool

Jakobi 2

51014 Tartu

andriela.raabis@ut.ee 


\title{
The linguistic means used in Estonian telephone conversation closings
}

\author{
Andriela Rääbis
}

The article studies closing sections in Estonian everyday telephone conversations. The research questions are as follows: What are the structural patterns of closing? What particular linguistic means are used in pre-closing and leave-taking sequences? Which factors can motivate the use of different social actions and linguistic forms?

The data for the study come from the Corpus of Spoken Estonian of the University of Tartu. A total of 209 everyday telephone calls were analysed.

The closing section consists of three parts:

- the pre-closing sequence,

- affiliation sequences (e.g. greetings to the family, promises to talk again, expressions of pleasure of the encounter etc.),

- the leave-taking sequence.

Pre-closings are linguistic expressions that indicate one's intention to terminate a conversation. They can be implicit or explicit. Implicit pre-closings involve minimal variants (okay, alright), arrangements, sum-ups, well-wishes, regards to other family members and expressions of appreciation. The other categories of expressions make explicit one's intention to end the call: "nothing else"-type utterances, mentioning external factors such as the reason for having to hang up the phone, references to the interlocutor's interests (I'll let you go) etc. Pre-closings are formed as either formulas (e.g. okay, thank you, see you soon, give my love to...) or longer sentences. Minimal tokens are preferred by children and teenagers (okay dominates), family members, and friends; they are typically used in information-seeking dialogues. Longer variants of pre-closings are characteristic of older participants, separately living family members and collateral relatives, and are generally used in 'keeping-in-touch' conversations.

Leave-takings are neutral or familiar formulas. Among younger people the dominant expression is ciao, which is hardly used at all by seniors, who appear to use more formal forms even with close friends and relatives.

Future studies could analyse which sequence types and linguistic means are used in affiliation sequences of closing sections.

Keywords: spoken Estonian, telephone conversation, closing section, pre-closing, leave-taking 